\title{
Innovation futures: new forms of innovation and their implications for innovation policy
}

\author{
Karl-Heinz Leitner \\ Innovation Systems Department, \\ AIT Austrian Institute of Technology, \\ Donau-City-Strasse 1, 1220 Vienna, Austria \\ E-mail: karl-heinz.leitner@ait.ac.at
}

\begin{abstract}
While new organisational models of innovation were intensively discussed in the last decade, there is little systematic exploration concerning their potential for different sectors and areas and their wider implications for economy and society. We present findings from an international foresight project which analyses and discusses the emergence and diffusion of new innovation patterns and their consequences for innovation policy. Based on a collection of international practice examples from industry and society, innovation visions have been generated and assessed involving different experts from all over Europe. A generic trend identified can be best described as open, distributed and networked innovation process which is to a certain extent already addressed in current innovation policy making. However, other trends such as the increased use of information technologies or new spatial shifts related to organising and doing innovation have rather been underestimated so far and will require new policy responses in the future.
\end{abstract}

Keywords: foresight; innovation models; innovation policy; open innovation; user innovation; grand challenges; sustainability.

Reference to this paper should be made as follows: Leitner, K-H. (2013) 'Innovation futures: new forms of innovation and their implications for innovation policy', Int. J. Foresight and Innovation Policy, Vol. 9, Nos. 2/3/4, pp.269-286.

Biographical notes: Karl-Heinz Leitner is a Senior Scientist at the Austrian Institute of Technology. He was a Visiting Research Scholar at the Copenhagen Business School and teaches innovation management at the Vienna University of Technology. His main research interests cover changing $R \& D$ and innovation processes, strategic management, research policy and the valuation of intellectual capital. Between 2009 and 2012, he coordinated the FP7 funded foresight project on the future of innovation (INFU).

\section{Introduction}

The way innovation is organised is changing. One hundred years ago, the Austrian economist Alois Schumpeter (1911) saw the entrepreneur and the development lab as prime locus of innovation. However, today innovation is seen as something happening anywhere at anytime. Emerging innovation models such as open innovation (Chesbrough, 
2003), user innovation (von Hippel, 2005), crowdsourcing (Howe, 2006) or community innovation (Tuomi, 2002) describe this development stressing that innovation is increasingly perceived as an open, distributed and networked phenomenon. Accordingly, innovation is not mainly driven by entrepreneurial firms but more often than not innovations are developed within a network of customers, universities, citizens and public organisations. New paths and arrangements for developing and adopting new products, services and solutions are driven by new technologies, the willingness of customers and citizens to contribute to innovations, global economic competition and rising educational backgrounds.

Most studies published in the innovation literature dealing with new forms of innovation such as open innovation, user innovation or community innovation address rather narrow research questions concerning, for instance, the motivation of the involved actors (Antikainen and Vaataja, 2010), the economic benefits (Lerner and Tirole, 2002), barriers for their introduction (Van der Meer, 2007) or the actual use and diffusion in certain industries (Lüthe and Herstatt, 2004). However, hardly any studies have been published exploring systematically and concurrently the potential future evolvement and diffusion of the numerous and different new forms of innovating. In this paper, we hence take a broader view aiming to investigate how different new patterns of innovation may evolve in the future and how they may change the innovation landscape. We thereby aim to enlarge our understanding of the innovation process and defined innovation patterns as the underlying principles on how the innovation process is organised which also includes new perceptions of what is seen as innovation, the involvement of new actors in the innovation process and the generation of new interpretations of the novel and the new in society.

Moreover, only a few studies published deal with the implications for innovation policy due to changing modes of innovation. Such studies, for instance, have been conducted to support open innovation (e.g., De Jong et al., 2008; Henkel and von Hippel, 2005), to analyse the role of intellectual property rights (IPR) (e.g., Gambardella et al., 2007; Guellec and Pottelsberghe, 2007), the promotion of eco-innovations (Bleischwitz et al., 2009) or the globalisation of innovation and its policy implications (e.g., De Backer and Hatem, 2010). Apart from the work of the OECD (2009), there is hardly any literature studying in a more systematic and forward looking manner the implications of the diverse new forms of innovation. By analysing and assessing the different innovation patterns, we aim to identify new directions for innovation policy and thereby challenge our understanding of the many different ways on which innovation is organised in diverse areas and how to promote it. Policy makers have to understand new innovation phenomena in order to benefit from the potential opportunities and risks for society and economy arising from these changes. In this context, a number of authors has also pointed towards the need for more fundamental changes using notions such as transformative innovation (Steward, 2008) or system transition (De Haan and Rotmans, 2011) which call for transformative visions and roadmaps which can challenge today's paradigms and basic assumptions on innovation and system dynamics (Warnke, 2011).

This paper addresses this gap in the literature by presenting results of an international foresight project which analyses and discusses the emergence and diffusion of new innovation patterns and their significance for European policy (Leitner et al., 2012). ${ }^{1}$ The Innovation Futures (INFU) project combined various foresight methods such as weak signal scanning (Hiltunen, 2008), expert panels (Godet, 1994), development and 
assessment of visions (Ronis, 2007; Koivisto et al., 2009) and builds on the existing academic literature on new innovation models (e.g., Chesbrough, 2003). The project comprised four distinctive phases with different methodological approaches:

1 screening for signals of change linked to innovation in a wide range of online and print media

2 stepwise clustering of the findings into visions in interaction with innovation actors through interviews and an online survey

3 development and assessment of visions of future innovation landscapes

4 development of policy implications (Schirrmeister and Warnke, 2013).

While foresight projects for supporting innovation policy making frequently deal with the development of technologies, often called technology foresight or future-oriented technology analysis (e.g., Georghiou et al., 2008), this project applies a foresight methodology addressing the question of the different possible development paths for organising the innovation process. This is in line with the fact that innovation activities increasingly occur in the non-technological area and that service innovations, social innovation or soft innovations are on the rise.

This paper is structured as follows. We firstly present the innovation visions which have been developed in the project. We then assess and discuss the innovation visions along six dimensions of change and discuss possible implications for innovation policy. We summarise the main findings in the last chapter.

\section{Identification of new patterns of innovation}

Until the beginning of the 1990s, the dominant definition of innovation as "new products and processes that are introduced to the market" combined with the common understanding of companies as the main actors in this process was hardly ever questioned, neither in the innovation management nor in the innovation policy literature. However, in the last two decades the innovation literature expanded our concepts and definitions of innovation. Nowadays, new innovation concepts are being suggested from a number of different directions. Increasingly, phenomena like open innovation (Chesbrough, 2003), user innovation (von Hippel, 2005), value innovation (Kim and Mauborgne, 1999), soft innovation (Stoneman, 2007), crowdsourcing (Howe, 2008), social innovation (Mumford, 2002), frugal innovation (Ray and Ray, 2010), and business model innovation (Osterwalder and Pigneur, 2010) are recognised as highly relevant innovation arenas extending its standard definition. At the same time, with the notion of open innovation, the focus on the firm as the key innovation actor has substantially broadened towards social entrepreneurs, users, customers, the public sector and citizens (Chesbrough, 2003; von Hippel, 2005). Following this broader view on innovation encompassing the economic, social and public domains, we understand innovation as the creation of new products, processes, technologies and services that are accepted by markets, governments and society.

In the first phase, by scanning 'weak signals' (Hiltunen, 2008), all sorts of observations of striking innovation practices were collected in a loose and open mode. Weak signals were defined as 'signals of emerging issues'. Our understanding included 
taking into consideration new ways of doing innovation in fields where they were previously unknown even if they were common in other areas. Thus, by new innovation patterns, we also understood well-known trends such as open source software development an alternative way to innovate, when observed outside the traditional software domain. The process of the emergence of new innovation patterns and the change of the innovation landscape may not necessarily be radical, however, phenomena which emerge in a specific industry or field may have a larger impact on other areas in the future.

The sources selected included daily newspapers from Europe and other world regions, daily newspapers with a business focus, magazines with a technological, business, or innovation focus and websites as well as blogs on innovation and research. Based on the scanning process which lasted six months, a total of 63 weak signals was identified. For each signal of change a possible impact on the future of innovation was estimated in an intuitive manner by the project members and briefly described in a template. The signals identified for change have revealed that many of the observed practices can be referred to as concepts or strategies which have partly been described in the academic literature, but often combine elements or strategies in a new manner or realise strategies for an entire new application field and thus expand the perception of possible innovation futures.

Based on a short description, the signals were clustered according to their possible impact. As a result, 19 clusters of signals of change were identified. Each cluster pointed towards a specific change in innovation patterns, derived from diverse signals of change from various sources of information. For each cluster, a fictive vision was developed by way of 'amplification' using the three principles

1 transfer of an idea or application to another sector of field

2 generalisation of the idea or concept as mainstream practice

3 radicalisation of the principle and questioning whether or not an idea can be brought to an extreme.

The results of this process were 19 visions which describe possible ways to create, develop and use innovations facilitating and provoking a debate on the future of innovation among actors from the business and policy domain. The visions were also visualised by so-called story-scripts (Jégou and Vincent, 2009) which combine pictures and drawings to express a fictive future situation (see Figure 1 for some selected examples). We briefly introduce some of the 19 innovation visions next. For a full list of all visions see Table 1 .

By the 'open source society' model, we envisaged that open source software design such as the development of the LINUX computer software (which competes successfully with Microsoft) has become a significant trend. This innovation vision assumes that open source development is no longer limited to software design but becomes an all-compassing innovation pattern. Many products and services are provided by a large number of people who contribute different bits and pieces to various technological and social innovation projects.

With 'web-extracted innovation', we assumed that a number of new techniques such as the semantic web analysis allows for automatising parts of the innovation process, ranging from idea generation via design to testing. In this model, sophisticated semantic web-filters track changes in consumer preferences and new ideas in real time, and automatically extract innovations with outstanding market potential. 
Figure 1 Visualisation of selected innovation visions (see online version for colours)

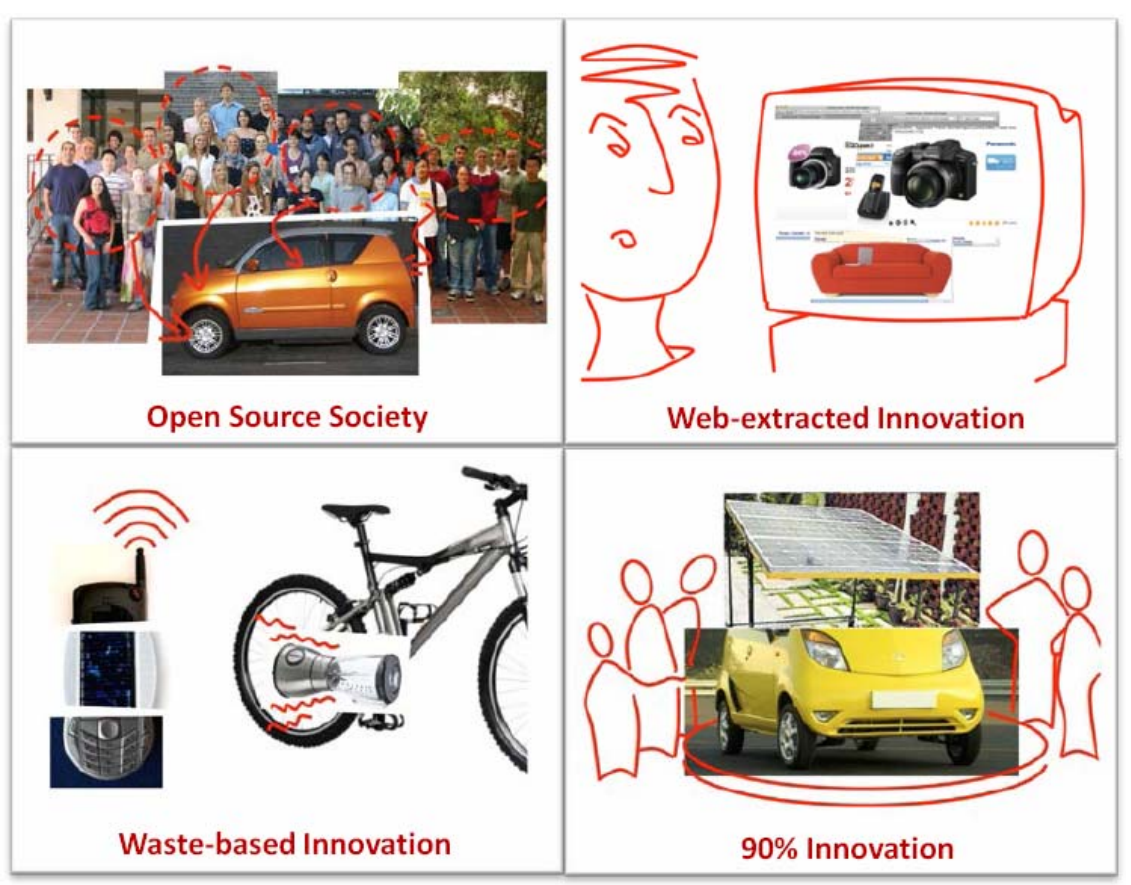

Table 1 The 19 innovation visions

\begin{tabular}{ll}
\hline Vision & Brief description... \\
\hline $\begin{array}{l}\text { Innovation on } \\
\text { request }\end{array}$ & $\begin{array}{l}\text { What if companies generate most innovations on special request from user } \\
\text { communities? }\end{array}$ \\
& $\begin{array}{l}\text { Together with sociologists, designers, and developers, communities of users } \\
\text { develop innovation scenarios and sell them to companies. }\end{array}$ \\
Deliberative & What if experimenting aligned social and technological innovation was at the \\
innovation & core of successful innovation systems? \\
& $\begin{array}{l}\text { Public authorities strive to foster a permanent stage of social experimentation } \\
\text { through a loosely connected network of local bottom-up projects. Enablers for }\end{array}$ \\
& $\begin{array}{l}\text { collective experimentation such as innovation toolkits form the critical } \\
\text { infrastructure for public experimentation. }\end{array}$ \\
Negotio-vation & $\begin{array}{l}\text { What if innovation becomes publicly negotiated? } \\
\text { Companies make open calls to citizens for innovation proposals, competing to } \\
\text { get 'innovation credits' from them in order to get approved the development } \\
\text { of the new product. } \\
\text { CIY - create it } \\
\text { yourself }\end{array}$ \\
& $\begin{array}{l}\text { What if fabrication laboratories for everybody with flexible manufacturing } \\
\text { products themselves? }\end{array}$ \\
& $\begin{array}{l}\text { Self-production of personalised objects (e.g., by 3D-Printers) is the standard } \\
\text { way of producing commodities directly at home or in 'create it yourself } \\
\text { shops/malls' with optional professional support. Companies just deliver } \\
\text { materials, components, equipment and design tools. Brands hardly play a role } \\
\text { any longer. }\end{array}$ \\
\hline &
\end{tabular}


Table 1 The 19 innovation visions (continued)

\begin{tabular}{|c|c|}
\hline Vision & Brief description... \\
\hline \multirow[t]{2}{*}{$\begin{array}{l}\text { Laboratory } \\
\text { stores }\end{array}$} & $\begin{array}{l}\text { What if stores were to become laboratories where companies and customers } \\
\text { co-develop innovations? }\end{array}$ \\
\hline & $\begin{array}{l}\text { Laboratory department stores would offer theme worlds such as 'family life' } \\
\text { or 'new sports', where customers can experience unreleased products, } \\
\text { individualise existing goods and in return get access to products fitting better } \\
\text { their needs and desires. }\end{array}$ \\
\hline \multirow[t]{2}{*}{$\begin{array}{l}\text { Innovation } \\
\text { marketplace }\end{array}$} & $\begin{array}{l}\text { What if companies no longer innovate themselves but fully externalise } \\
\text { innovation to an open innovation marketplace? }\end{array}$ \\
\hline & $\begin{array}{l}\text { Nomadic innovators would bid on innovation tender and contests with } \\
\text { constantly changing teams. They would gather in co-working spaces, some of } \\
\text { which are top-favourite employers for creative people. }\end{array}$ \\
\hline \multirow{2}{*}{$\begin{array}{l}\text { Innovation } \\
\text { campus }\end{array}$} & What if companies collaborated in places of joint innovation? \\
\hline & $\begin{array}{l}\text { Independent innovation plants will rent large open spaces for companies to } \\
\text { settle their innovation staff with private areas and many types of collaborative } \\
\text { facilities in between. }\end{array}$ \\
\hline \multirow[t]{2}{*}{ Innocamps } & $\begin{array}{l}\text { What if innovation camps, where people gather for a few days to innovate, } \\
\text { become widely established as a means of problem solving? }\end{array}$ \\
\hline & $\begin{array}{l}\text { Innovation camps are used by companies, public sector and civil society to } \\
\text { solve problems from high-tech challenges to neighbourhood facilities. Most } \\
\text { people join innovation camps on a regular basis. }\end{array}$ \\
\hline \multirow[t]{2}{*}{$\begin{array}{l}\text { Open source } \\
\text { society }\end{array}$} & $\begin{array}{l}\text { What if open source development is no longer limited to software } \\
\text { development but becomes an all encompassing innovation pattern? }\end{array}$ \\
\hline & $\begin{array}{l}\text { Many products and services are provided by people contributing bits and } \\
\text { pieces to various technological and social innovation projects. Open source } \\
\text { business models and coordination mechanisms abound. }\end{array}$ \\
\hline \multirow{2}{*}{$\begin{array}{l}\text { Virtual-only } \\
\text { innovation }\end{array}$} & What if many innovations were enjoyed only virtually? \\
\hline & $\begin{array}{l}\text { Virtual-only products satisfy human appetites for newness. They are } \\
\text { displayed in virtual galleries for public perception or projected into homes } \\
\text { and offices for individuals on demand. Most of these products never } \\
\text { materialise. }\end{array}$ \\
\hline \multirow[t]{2}{*}{$\begin{array}{l}\text { Darwin's } \\
\text { innovation }\end{array}$} & $\begin{array}{l}\text { What if companies use digital systems to randomly create and test innovation } \\
\text { variants before selecting the 'fittest' for further development? }\end{array}$ \\
\hline & $\begin{array}{l}\text { A number of variants are tested often with unexpected outcomes. Design, } \\
\text { creativity and consumer research lose relevance. Engineers dream of } \\
\text { ultimately simulating the end-user and thus fully automate the innovation } \\
\text { process. }\end{array}$ \\
\hline \multirow[t]{2}{*}{$\begin{array}{l}\text { Web-extracted } \\
\text { innovation }\end{array}$} & $\begin{array}{l}\text { What if we scan the internet for ideas and automatically pick the ones that } \\
\text { best answer current customer needs? }\end{array}$ \\
\hline & $\begin{array}{l}\text { Sophisticated semantic web-filters track changes in consumer preferences and } \\
\text { new ideas in real time, and automatically extract innovations with outstanding } \\
\text { market potential through big data. }\end{array}$ \\
\hline \multirow[t]{2}{*}{$\begin{array}{l}\text { Ubiquitous } \\
\text { innovation }\end{array}$} & $\begin{array}{l}\text { What if the current emphasis on innovation and creativity for designers, } \\
\text { programmers and engineers spreads to all workplaces? }\end{array}$ \\
\hline & $\begin{array}{l}\text { All employees from the janitor to top management are constantly involved } \\
\text { into innovation activities. Creativity is part daily job routine and is key in } \\
\text { performance measurements. Part of the job is to redefine the job itself. }\end{array}$ \\
\hline
\end{tabular}


Table 1 The 19 innovation visions (continued)

\begin{tabular}{|c|c|}
\hline Vision & Brief description... \\
\hline \multirow{2}{*}{$\begin{array}{l}\text { Innovation } \\
\text { meets } \\
\text { education }\end{array}$} & $\begin{array}{l}\text { What if innovation skills were high on the education agenda right from } \\
\text { kindergarden? }\end{array}$ \\
\hline & $\begin{array}{l}\text { Children are motivated to maintain their 'discovery spirit' and learn how to } \\
\text { question facts and think differently. Learning is project oriented with a high } \\
\text { emphasis on bricolage. Innovation becomes something that is taught as a } \\
\text { matter of course, just like the ABCs. }\end{array}$ \\
\hline \multirow[t]{2}{*}{ No-innovation } & What if innovation fatigue takes over and no-innovation is en-vogue? \\
\hline & $\begin{array}{l}\text { The innovation rush is finally slowing down. Product cycles are becoming } \\
\text { longer again. For market success, unchanging quality is more important than } \\
\text { ever new offers. }\end{array}$ \\
\hline \multirow[t]{2}{*}{$\begin{array}{l}\text { City-driven } \\
\text { innovation }\end{array}$} & $\begin{array}{l}\text { What if cities became stronger actors in the field of innovation by proactively } \\
\text { pushing for necessary solutions? }\end{array}$ \\
\hline & $\begin{array}{l}\text { Cities could take on the investment risks for the development and } \\
\text { implementation of innovations that are needed and use this as a new } \\
\text { economic factor by patenting and marketing their solutions to other cities. }\end{array}$ \\
\hline \multirow[t]{2}{*}{$\begin{array}{l}90 \% \\
\text { innovation }\end{array}$} & $\begin{array}{l}\text { What if innovation is primarily directed at the 'other } 90 \% \text { ' of the world } \\
\text { population living in poverty? }\end{array}$ \\
\hline & $\begin{array}{l}\text { Extreme low cost/high innovation strategies prevail. Wealthy global } \\
\text { companies struggle as they lack the competencies and culture required. } \\
\text { Innovators from today's' emerging markets do much better due to their } \\
\text { longstanding experience. }\end{array}$ \\
\hline \multirow[t]{2}{*}{$\begin{array}{l}\text { Relocated } \\
\text { innovation }\end{array}$} & $\begin{array}{l}\text { What if the bulk of successful and disruptive innovations were to come from } \\
\text { today's emerging markets? }\end{array}$ \\
\hline & $\begin{array}{l}\text { The West adopts the role of a follower and has to face products primarily } \\
\text { designed for different cultural contexts. Western companies look to Asia, } \\
\text { often with the help of industrial espionage. Creative people migrate to the } \\
\text { new innovation hot spots in Asia and send back their money home to the } \\
\text { USA and Europe. }\end{array}$ \\
\hline \multirow[t]{2}{*}{$\begin{array}{l}\text { Waste-based } \\
\text { innovation }\end{array}$} & $\begin{array}{l}\text { What if the principle of 'waste equals food'/'cradle-to-cradle' got widely } \\
\text { adopted? }\end{array}$ \\
\hline & $\begin{array}{l}\text { Instead of raw material, databases with used components and materials serve } \\
\text { as a starting point for innovations. The whole world becomes one eternal } \\
\text { circle. Everything that is made of something is part of making something else. }\end{array}$ \\
\hline
\end{tabular}

The vision of 'relocated innovation' envisages that the West adopts the role of a follower while Asian countries become innovation leaders. Western companies wishfully have to face products primarily designed for a different cultural context and imitate and copy products from Asia. Creative people might even migrate to the new innovation hot spots in Asia and send their salaries back home to the USA and Europe. The current tendencies of 'globalisation of wisdom' would hence be limited by specialised regional innovation clusters. In addition, Western Nations would lose wealth while people in the Middle East and Asia would benefit.

'Innovation marketplace' is described as an innovation pattern where companies externalise (parts of the) innovation processes to an open innovation marketplace. Companies may be able to draw on a much broader range of ideas and perspectives. They can manage their innovation processes more flexibly and efficiently. At the same time, 
'nomadic innovators' bid on innovation tenders and contests in constantly changing teams within this scenario.

In the innovation vision 'deliberative innovation' citizens are expected to play a more important role both in governing and implementing innovation activities. This innovation model driven by citizens can be best described as a deliberative bottom-up innovation process. The dynamics of cities as hubs and generators for innovation processes was particularly stressed by the related 'city-driven innovation' vision. In particular, systemic sustainability innovations may best be implemented on a city level in the future.

'Waste-based innovation' explicitly deals with the issue of sustainable productionconsumption patterns and the emergence of an innovation model that is fully consistent with a circular flow of resources. McDonough and Braungart (2002) conceptualised this idea as 'cradle-to-cradle principle', where novelties emerge out of recycled and re-used products. The Dutch city of Venlo was identified as an example as it adopted this idea and wants to radically avoid waste by 2015 . However, this was not the only innovation vision that explicitly deals with sustainability issues. Most innovation visions emphasise the need to address societal challenges and, in particular, environmental issues as a key driver of change not only for the target or output of innovation but also for the innovation process.

The innovation vision 'negotio-vation' means that innovation becomes publicly negotiated. Companies, for instance, advertise innovation proposals to citizens and potential customers, who, in turn, vote or approve of product proposals and thereby steer the direction of development.

With 'ubiquitous innovation' we expect innovation to become mandatory for more and more people in companies and other types of organisations. The assumption is that the current emphasis on innovation and creativity among designers, programmers, and engineers will spread to all workplaces. Hence, all employees, from janitor to top manager are constantly involved in innovation activities. Creativity is part of any daily job routine and is a key in performance measurements.

A reverse trend may be that innovation fatigue takes over and 'No-Innovation' becomes en-vogue in certain areas and emerges as a trend in itself. This critical and rather sceptical innovation vision was the only vision among all the 19 visions that explicitly expresses a 'de-acceleration' of the current innovation practice.

\section{Assessment and implication of the innovation visions}

In order to assess the different innovation visions and to discuss their consequences for innovation policy, a number of methods have been deployed in the project. We conducted interviews with industrial and academic experts, organised workshops and implemented an survey. In the first stage, an online-survey was launched to assess the 19 innovation visions. We contacted researchers, consultants, industry managers and inventors with diverse backgrounds (education, age, gender) to participate in the survey with the aim to assess the visions with respect to newness, impact, desirability and likelihood. In total, 56 experts participated in the survey.

The survey revealed that the majority of participants considered the visions to be quite self-explanatory. As to the desirability of the visions, the respondents showed clear 
preferences and disapprovals. Seven out of the 19 visions were evaluated as desirable by more than $70 \%$ of the participating experts. From these seven, the visions 'waste-based innovation' and 'innovation meets education' were mostly considered as 'desirable'. Conversely, two visions were evaluated as 'non-desirable' by more than $70 \%$ of the participants: 'no-innovation' and 'virtual-only innovation'.

There seems to be a no consensus amongst the experts, though, on the expected economic and social impact of the visions as they were evaluated quite differently. Visions focusing on the way the internet was integrated in the idea generation (e.g., innovation visions 'Darwin's innovation', 'web-extracted innovation' and 'innovation marketplace') were considered as having a low impact while the location of the innovation processes (visions 'relocated innovation' and ' $90 \%$ innovation') was contemplated as having a high impact.

In terms of likelihood, there appears to be no big difference between the innovation visions. The likelihood of all 19 visions seems to be quite uncertain. None of the visions was considered as 'very likely' by more than $20 \%$ of the experts participating in the online surveys. Two of the visions were considered to be very unlikely ('negotio-vation', 'no-innovation'). Both visions can be characterised as rather pessimistic visions that describe a slowing down of the innovation process. However, the experts who participated seemed to be convinced that the innovation dynamic was not going to slow down but was going to increase in the future and that those innovation visions were rather unlikely to become true.

In addition to the information gathered by the survey, we further expanded the assessment by conducting interviews and organising nine working groups across Europe involving more than 70 experts. The experts were identified and contacted by members of the project team with the aim to have a group of people with a high diversity concerning their background and experiences with creating, supporting, managing and using innovation in different fields. The experts invited came from more than 13 different countries, mainly but not only Europe and had an industry, academia or policy maker background. Thereby, the opportunities and threats of the visions concerning the economy, society and eco-system were discussed in more depth.

For a more elaborated assessment of the innovation visions, a conceptual framework was developed. The framework was designed based on the review of academic literature on innovation patterns and the initial analysis of the signals of change and aimed to support the analysis of structural changes of the innovation landscape. The framework consists of six 'dimensions of change' which describe those key characteristics which are common to most of the emerging innovation models and visions created within the project. The first dimension 'mediation and coordination', for instance, deals with the question whether innovations are more demand-driven or supply-driven and hence addresses the classical question of technology-push versus demand-pull innovations (e.g., Lundvall, 1988; Rothwell, 1992). We found that many new innovation models indicate a shift towards demand-driven innovation combined with a much more diffused participation of different actors in the innovation process.

For each of the dimensions of change, challenges for innovation policy and directions for new policy interventions were discussed which will be described next. The task was not to develop specific policy recommendations but to deliver some evidence of new directions and challenges for policy on the European level. 


\subsection{Dimension 1: mediation and coordination}

With this dimension, we propose that the position of markets as the main mediator between innovation demand and supply is challenged by several new innovation patterns. Coordination mechanisms such as self-organised user communities, web-based co-design platforms or innovation initiatives on the city level involving public and private actors are on the rise and are complementary to market mechanisms or even substituting them. Citizens and customers will play a more relevant role in innovation in the future, both in deciding on innovation priorities and in contributing to the innovation process.

The emergence of new mediation mechanisms requires a policy that takes a leading part in making new forms and patterns of innovations more visible and therefore also eligible for funding. Self-organised and network-based innovation activities are usually managed by a combination of formal mechanism (e.g., terms and conditions, legal framework) and informal mechanisms (trust and relationships) which require specific policy interventions (Marjanovic et al., 2012). Policy should serve as a facilitator of the newly emerging non-market based collective innovation activities. This, however, entails a number of policy innovations. Self-organised networks of innovating individuals will have to be considered as a relevant target group for innovation policy measures. Projects with new formats will be required that involve diverse actors from many realms in joint learning processes. These measures will have to be coordinated diverse policy realms and bridge across public and private sector initiatives. While many research promotion programs such as the European Framework Programmes are currently focusing on technological innovations with participants from academia and business, new forms and projects with more diverse participation may be funded in the future.

Finding the right level, scale and instruments to enable participatory co-creation of solutions seems a crucial future policy challenge. Adequate consultation processes where people are motivated to contribute must be developed. Participatory procedures that fit today's modes of group interaction such as web 2.0 procedures should be developed, tested and deployed. However, participation procedures need to be tailored to different phases of the policy process, such as: idea generation, visioning, up-scaling, co-production of solutions, political involvement, funding through citizens. Also, the right scale for involvement needs to be carefully adapted (Stirling, 2005). Not everybody can be an expert in everything and too many requests for contribution will lead to overload and fatigue.

This implies a change in the role of policy makers towards mediators within a wide range of coordination activities. Such a role is also in line with arguments based on the systems theory which argues that policy should govern the system by assuring the adaptation capabilities of innovation systems and by establishing rules which foster the self-organisation capabilities of different actors (e.g., Rhodes, 1997; De Haan and Rotmans, 2011).

\subsection{Dimension 2: motivation}

The motivation for innovation is changing. Intrinsically motivated users, communities, citizens, and social entrepreneurs add their motivations to company innovation activities, complementing the typical driver of profit motive. Solving societal problems is becoming an important driving force for innovating, for both companies and individuals. A number of examples identified within the project reveals that individual actors are motivated to 
contribute to innovation activities, e.g., by crowdsourcing initiatives or idea competitions for their pleasure. The expanded circle of stakeholders and participants in innovation processes are often driven by intrinsic motivations and related to new coordination mechanisms, often based on participatory processes and user involvement.

In addition, the direction of innovation development should be guided by providing orientation with the help of demand-side innovation policies such as public procurement, objective-driven innovation policies, increased labelling and giving meaning to products and innovations. Such policies are currently discussed and implemented on the European level (EC, 2010) and thus the results of our project support the necessity to adopt such policies.

Moreover, non-commercial and social innovations together with changing motivation patterns also need new measurements and indicators, as well as evaluation criteria and methods. The impact of innovations does not just result in economic growth, but e.g., changes in quality and well-being. At the same time, motivation patterns to innovate also need a fair share of gained profits (monetary and non-monetary) to keep individuals motivated. This transformation goes hand in hand with the upcoming change in growth paradigm and the measurement of wealth progress which also focus on quality of life and do not just increase the number of innovations (GGGI et al., 2013). Thus, policy more often than in the past has to address the question of the purpose of innovation which goes beyond the dominant rationale to foster competitiveness and economic growth.

In this context, policy for social innovation and social entrepreneurship should be strengthened. The study findings deliver further evidence for the usefulness of activities the Commission has already set up most recently to foster social innovation and social entrepreneurship (e.g., EC, 2010). However, we still have to better understand how to support social innovation and social entrepreneurship and their differences to traditional entrepreneurial activities mainly driven by seeking profits.

In addition, policy needs to help establish and develop clear and transparent rules for the ownership of innovation, product liability and the fair distribution of benefits. This expands the traditional focus of innovation policy on IPR (Guellec and Pottelsberghe, 2007). When innovation activities are no longer primarily directed at money-making, the current IPR system no longer fits the innovation landscape and hinders the transition towards co-designing landscapes that enable new forms of innovations (e.g., Henkel and von Hippel, 2005). However, new strategies such as public domain, copyleft and creative commons help to transform the IPR systems and provide a safe base for experimentation.

\subsection{Dimension 3: automatisation}

Software will play an ever-growing role in innovation as some identified international examples show. In this model, sophisticated semantic web-filters track changes in consumer preferences and new ideas in real time, and automatically extract the innovations with outstanding market potential. More and more innovation steps may become automatised, e.g., by using a web crawler to identify ideas.

As a response to this trend with very diverse impacts on business and society, policy measures should reinforce the use of powerful algorithms for a more accurate assessment of complex systems, supported by open availability of data (open data). Simulation-based ex-ante evaluation of policy measures with respect to environmental and societal impact could be a positive effect of automatised innovation processes. 
However, policy should be aware of the risks of an increased automatisation of innovation and possible, unintended long-term effects on creativity.

Concerning the use of information and communication technologies to run (parts) of the innovation process, ex-ante principles could guide the use of digital data for such innovation purposes and, after gathering relevant evidence, could simultaneously lead to (ex-post) legislation and regulation without over-protecting and hindering automatised innovation. Such stringent principles, for example, could guide the protection of intellectual property, user rights and the transparency of data as well as the (fair) share of profit and value created with the data. Content policy, interoperability and standardisation issues to prevent monopolisation of data processing and storage should become issues of ever-growing importance. While the European Commission and academia have already addressed the question on how open innovation and social innovation can be fostered (e.g., De Jong et al., 2008; EC, 2010), the awareness of possibilities to automatise the innovation process is rather limited and has not been discussed sufficiently.

Against this background, a public debate and campaign may be initiated which reflect on the role and positioning of the individual in the information society and, at the same time, supports individuals in positioning themselves in the digital reality as mature users and data providers. This debate has already started and can lead to guiding principles about data rights and processing that will become increasingly important in our societies (Hoyer, 2012).

\subsection{Dimension 4: new infrastructures}

A number of new innovation models is associated with the emergence of new infrastructures. In particular enabling infrastructures for community innovation, such as innovation camps, shared fab-labs and co-working spaces are likely to become more important in the next year. In addition, virtual or digital global innovation infrastructures may become increasingly vital.

Policy may support the setting-up of such infrastructures (meeting places, living-labs, fab-labs, innocamps, etc.) with low entry barriers for people from all kinds of backgrounds and thereby enable widespread self-production beyond the 'creative class'. Pilot projects could be funded within existing innovation funding schemes, but also new, more experimental types of projects not only involving companies and researchers, but also civil society actors would be required. A call which is also supported by the concept of strategic niche management (Hoogma et al., 2002). Micro-grants and tax breaks could be used to support people who want to organise such camps, fab-labs and other innovation infrastructure projects.

\subsection{Dimension 5: spatial shifts}

Innovation will change its spatial patterns in the future. Local elements are likely to gain relevance, resulting in a more distributed innovation scenery. At the same time, new regions emerge as key actors in global innovation chains.

Two types of policies are needed regarding the regional shifts of innovation. Firstly, policies are needed which support globally acting companies to pursue new types of strategy. For instance, European companies can choose reverse innovation strategies, split the design and production of low-cost products and sell them worldwide. In addition, companies may tailor their products to the requirements of these local contexts 
and emerging markets. Consequently, policy should reduce barriers so that European companies can expand their R\&D activities overseas enabling them to conduct global collaboration arrangements. Policies which foster the development of such products have not been debated on the European level so far.

Secondly, due to the growing importance of innovation emerging on the regional and city level, i.e., regionalisation of innovation activities, European research and innovation policy should support regional demonstration projects. However, it is not just about enabling and supporting (large-scale) demonstration and testing initiatives, but also about making sure that the results of such projects are transferable to other regions and markets, also outside the European Union. Policy should therefore support the development of services and measures that enable such transfers and enhance the return of these investments.

\subsection{Dimension 6: systemic sustainable innovation}

Innovation patterns fostering system transitions towards sustainability rather than isolated product developments become more and more important when it comes to tackling the societal challenges. This requires, for example, that social and ecological criteria are considered during the entire innovation process, e.g., by designing circular resource flows following a cradle-to-cradle strategy (McDonough and Braungart, 2002).

Recently, the idea that public support for research and innovation should address the 'grand challenges' of our times and thereby contribute to the sustainable development of our society has received wide attention (e.g., HLG, 2008; OECD, 2009; EC, 2010). However, if we are serious about addressing the 'grand challenges', policy needs to support socio-technical system transitions. We need to break away from lock-in in non-sustainable socio-technical paradigms and underpin industrial transformation. This requires more than just a shift in priorities that is already underway in many strategies, such as EU2020. Fostering systemic innovations is challenging for policy as it goes beyond just promoting individual 'intelligent' projects, but requires adopting a really systemic view encompassing comprehensive impact assessments, a long-term strategy perspective, the coordination of projects and the existence of a system integrator. To obtain successful system transition insights into society, lifestyle values and culture are as important as technological knowledge.

To explore successful transition trajectories, we need to integrate perspectives from engineering and natural sciences, on the one hand, and humanities and social sciences on the other. To this end, research projects with this kind of trans-disciplinary collaboration on an equal footing should be explicitly supported. Furthermore, in order to understand and promote the societal benefit of new technological solutions, it will be necessary to extend research and innovation funding beyond the early stages of research towards the exploration of their societal embedding.

Policy may need to focus on the enabling framework for the four pillars of the innovation system referring to the quadruple helix approach (Arnkil et al., 2010): the co-evolution of government, knowledge institutions, industry, and civil society. Such a view is also proposed by the literature stream on the social shaping of technology which assumes that participation by many innovation systems actors along the entire innovation process is required in order to balance the different economic, social and environmental impacts of innovation and to minimise any negative impacts (Schot, 2001). Under such a framework, policy should aim at developing images of and pathways towards the future, 
as well as at specifying the elements and working configurations that are relevant on the different levels of a transition process towards a newly emerging and often more sustainable paradigm.

\section{Summary}

While most studies to date have investigated specific and single forms of innovation and their impact on economy and society (e.g., Henkel and von Hippel, 2005; De Jong et al., 2008), in this paper we take a broader view aiming to investigate how different innovation models may evolve in the future. For the first time, a foresight project was conducted to analyse and discuss the future development of new innovation patterns and their implications for European policy. In order for research, innovation and other policies to be prepared for challenges arising from these changes and to be able to benefit from them, a more solid understanding of possible innovation futures and their implications for society is needed. When investigating new patterns of innovation, we focussed on the fundamental transformation in the way innovation is organised in business, the public sector and society.

Based on the signals of change identified, we generated and visualised 19 innovation visions. These visions were formulated in a creative way by amplifying and combining some of the signals in order to develop coherent and sometimes provocative pictures of possible future innovation practices. In addition, we conducted interviews with industrial and academic experts, organised panels and implemented an online-survey to assess the innovation visions and discuss the implications for innovation policy.

A main trend of all the examples identified and visions can best described as the opening of the innovation process which is expected to continue and become even stronger in the years to come. Innovation models and examples such as the organisation of innovation contests, crowdsourcing projects, innovation camps, open source software development, online voting for the approval of new products and other forms of user involvement all provide evidence for this development. Open innovation, user innovation and community innovation is probably not a new or emerging phenomenon but already a significant trend. However, at the moment and in the future, this phenomenon is very likely to diffuse not only across industries but also the public sector.

The development in relation to opening up the innovation process is not just driven by companies which, for instance, organise innovation contests or crowdsourcing projects. Flexible working patterns, outsourcing and the increasing number of professional freelancers, foster and enable the emergence of new organisational innovation strategies. The further individualisation of society is a driver for this development, which, as one effect amongst others, increases people's ambitions to express themselves. By influencing the design of products, individuals may change the functionality of solutions and services according to their individual needs. Due to the growing awareness of customers and citizens to shape the direction of innovation and enhance the quality of the innovation output, the innovation process is becoming more and more deliberative and consultative.

The motivation of organisations and individuals to develop innovation is changing as well. Intrinsically motivated users, communities, citizens, and social entrepreneurs add their motivations to company innovation activities, complementing the typical driver of profit motive. The growing awareness of climate change, social tensions, and the 
inefficient use of resources are driving forces for changes in innovation patterns. Solving societal problems becomes an important driver to innovate, for both companies and individuals. In addition, people are motivated to contribute to innovation activities, for instance, within open source communities, crowdsourcing initiatives or idea competitions. There is evidence for a change in the way innovators and the fact of being innovative is socially rewarded in so far as being innovative is becoming more socially desirable for a growing number of people.

Technology is a driver for how we organise the innovation process: from idea creation to the launch of new products and services on the market. From a technological perspective, especially new Web 2.0 applications and software algorithms are bringing about changes in innovation patterns, as they facilitate the sharing of knowledge and collaboration and render them more affordable on a global scale. However, it is difficult to envisage the long-term impacts of such a development. Speeding up the innovation process, combined with the ease of copying software algorithms, may lead to difficulties in protecting IPR in a globalised world. Moreover, too many standardised creative processes may after all hamper creativity. This reveals new questions for policy making which have not gained much attention on the European level so far.

The future of innovation is open, socially, and environmentally-driven on the one hand and faster and more global on the other. However, that would be too easy, too simple and too generic conclusion. The project has revealed a much more diverse and broad future for innovation, indicating some tensions and ambivalent developments: The future will bring about more participation raising the question, when the limits of participation are reached and when too much participation results in lukewarm solutions or the slowing down of the innovation process, a debate which has not emerged on the policy agenda and also delivers new questions for academic research (e.g., Sveiby et al., 2012).

Within the project, we have identified important directions and challenges for innovation policy. Some topics and issues such as the need for fostering open innovation, addressing societal challenges, reforming the IPR regime and responding to the emerging global innovation landscape have already gained much attention within recent policy making on the European and international level (e.g., Aho et al., 2006; OECD, 2009; EC, 2010) and our findings underpin the necessity to strengthen such policies. The European Commission has already pointed out the role of changing patterns of innovation in the 'innovation union strategy'. According to the European Commission, companies innovate in various ways: "While some conduct R\&D and develop new technologies, many base their innovations on existing technologies or develop new business models or services driven by users and suppliers, or within clusters or networks. Policies must therefore be designed to support all forms of innovation, not only technological innovation". In this context, an EU project dealing with open innovation and public policy (De Jong et al., 2008), for instance, has recommended to support collaboration, networking, and corporate entrepreneurship to foster open innovation. However, we also offer lessons for policy which go beyond these topics. In particular, the necessity to provide new forms of infrastructure, the increasing role of software with its significant positive but also undesirable effects, and the need to use new indicators considering the importance of value-driven innovations addressing social and environmental needs reveal new directions for policy-making.

Moreover, in order to ensure that progress towards grand challenges is made, in many fields real transformation on a system level is required which goes beyond the isolated 
development of individual actors and requires a systemic transformation (Grin et al., 2010). This means, for example, that social and ecological criteria are considered during the entire innovation process and coordination among many actors from the economy, science, policy and civil society is required, exceeding superficial consultation. In many cases, a system integrator has to be established, a role which can be fulfilled by the public but also private actors. This implies a changing role of policy making which exceeds the direct promotion of investments in research and development and requires much more co-ordination, orientation, facilitation of self-organisation, and the promotion of interdisciplinary approaches. Such a policy is in line with arguments based on the systems theory which call for a high level of participation for co-designing and the shaping of technological development, also triggered by constructing common visions for the future development (Weber, 2005; Joly et al., 2010).

The pace of innovation will continue into the future. Individual, organisational, and public actors will be part of the innovation process, influencing the direction of innovation. However, joint efforts are needed to shape this development and unlock the positive potential of innovation to solve the needs of society. Innovation policy has a key role in governing this development and steering it in the right direction.

\section{Acknowledgements}

The Innovation Futures (INFU) project has been supported by the 7. Framework Programme of the European Commission.

\section{References}

Aho, E., Cornu, J., Georghiou, L. and Subirá, A. (2006) Creating an Innovative Europe, Report of the Independent Expert Group on R\&D and Innovation appointed following the Hampton Court Summit, Office for Official Publications of the European Communities, Luxembourg.

Antikainen, M. and Vaataja, H. (2010) 'Rewarding in open innovation communities. How to motivate members?', International Journal of Entrepreneurship and Innovation Management, Vol. 11, No. 4, pp.18-26.

Arnkil, R., Järvensivu, A., Koski, P. and Piirainen, T. (2010) Exploring Quadruple Helix. Outlining User-oriented Innovation Models, Final Report on Quadruple Helix Research for the CLIQ project University of Tampere, Institute for Social Research, Työraportteja 85/2010 Working Papers.

Bleischwitz, R., Bahn-Walkowiak, B., Irrek, W., Schepelmann, P., Schmidt-Bleek, F. et al. (2009) Eco-innovation - Putting the EU on the Path to a Resource and Energy Efficient Economy, European Parliament, Brussels.

Chesbrough, H. (2003) Open Innovation. The New Imperative for Creating and Profiting from Technology, Harvard University Press, Boston.

De Backer, K. and Hatem, F. (2010) Attractiveness for Innovation. Location Factors for International Investment, OECD, Paris.

De Haan, J. and Rotmans, J. (2011) 'Patterns in transitions: understanding complex chains of change', Technological Forecasting and Social Change, Vol. 78, No. 1, pp.90-102.

De Jong, J., Vanhaverbeke, W., Kalvet, T. and Chesbrough, H. (2008) Policies for Open Innovation: Theory, Framework and Cases, Research project funded by VISION Era-Net, Helsinki.

EC (2010) Europe 2020 Flagship Initiative - Innovation Union - COM(2010) 546 Final, Brussels. 
Gambardella, A., Giuri, P. and Luzzi, A. (2007) 'The market for patents in Europe', Research Policy, Vol. 36, No. 8, pp.1163-1183.

Georghiou, L., Cassingena Harper, J., Keenan, M., Miles, I. and Popper, R. (Eds.) (2008) The Handbook of Technology Foresight, Edward Elgar, Cheltenham, UK.

GGGI, OECD, UNEP and World Bank (2013) Moving Towards a Common Approach on Green Growth Indicators, A Green Growth Knowledge Platform Scoping Paper, Global Green Growth Institute, Paris.

Grin, J., Rotmans, J. and Schot, J. (2010) Transitions to Sustainable Development, New Directions in the Study of Long Term Transformative Change, Routledge, New York/London.

Guellec, D. and Pottelsberghe, B. (2007) The Economics of the European Patent System: IP Policy for Innovation and Competition, Oxford Press, Oxford.

Henkel, J. and von Hippel, E. (2005) 'Welfare implications of user innovation', Journal of Technology Transfer, Vol. 30, Nos. 1/2, pp.73-87.

Hiltunen, E. (2008) 'The future sign and its three dimensions', Futures, Vol. 40, No. 3, pp.247-260.

HLG (2008) Challenging Europe's Research: Rationales for the European Research Area (ERA), Report of the ERA Rationales Expert Group, Brussels.

Hoogma, R., Kemp, R., Schot, J. and Truffer, B. (2002) 'Experimenting for sustainable transport', The Approach of Strategic Niche Management, EF\&N Spon, London.

Howe, J. (2006) 'The rise of crowdsourcing', Wired, Vol. 14, No. 6, pp.1-5.

Hoyer, B. (2012) Unlocking the Digital Future through Open Innovation: An Intellectual Capital Approach. A Critical Analysis of Open Innovation as Structural Capital, European Commission, DG Information Society and Media, Brussels.

Jégou, F. and Vincent, S. (2009) 'Co-design approaches for early phases of augmented environments', in Lahlou, S. (Ed.): Designing User Friendly Augmented Work Environments From Meeting Rooms to Digital Collaborative Spaces, Springer Verlag, London.

Joly, P-B., Rip, A. and Callon, M. (2010) 'Re-inventing innovation', in Arentsen, M.J., Van Rossum, W. and Steenge, A.E. (Eds.): Governance of Innovation: Firms, Clusters and Institutions in a Changing Setting, pp.19-32, Elgar, Cheltenham.

Kim, W.C. and Mauborgne, R. (1999) 'Strategy, value innovation, and the knowledge economy', Sloan Management Review, Vol. 40, No. 3, pp.41-45.

Koivisto, R., Wessberg, N., Eerola, A., Ahlqvist, T., Kivisaari, S., Myllyoja, J. and Halonen, M. (2009) 'Integrating FTA and risk assessment methodologies', Technological Forecasting and Social Change, Vol. 76, No. 9, pp.1163-1176.

Leitner, K-H., Jegou, F., Warnke, P., Mahn, J., Steinmüller, K.H., Rhomberg, W., von Salvern, S., Schirrmeister, E. and Watkins, V. (2012) Deliverable 7.3: Final Report - INFU Result and Guideline Brochure, Project funded within the 7th Framework Programme of the European Commission.

Lerner, J. and Tirole, J. (2002) 'Some simple economics of open source', Journal of Industrial Economics, Vol. 50, No. 2, pp.197-234.

Lundvall, B. (1988) 'Innovation as an interactive process: from user-producer interaction to the national system of innovation', in Dosi, G., Freeman, C., Nelson, R.R., Silverberg, G. and Soete, L. (Eds.): Technical Change and Economic Theory, pp.348-369, Pinter, London et al.

Lüthe, C. and Herstatt, C. (2004) 'The lead user method: an outline of empirical findings and issues for future research', R\&D Management, Vol. 34, No. 5, pp.553-568.

Marjanovic, S., Frey, C. and Chataway, J. (2012) 'Crowdsourcing based business models: in search of evidence for innovation 2.0', Science and Public Policy, Vol. 39, No. 3, pp.318-332.

McDonough, W. and Braungart, M.W. (2002) Cradle to Cradle: Remaking the Way We Make Things, North Point Press, New York.

Mumford, M.D. (2002) 'Social innovation: ten cases from Benjamin Franklin', Creativity Research Journal, Vol. 14, No. 2, pp.253-266. 
OECD (2009) New Nature of Innovation, OECD, Paris.

Osterwalder, A. and Pigneur, Y. (2010) Business Model Generation, John Wiley, Hoboken.

Ray, P.K. and Ray, S. (2010) 'Resource-constrained innovation for emerging economies: the case of the Indian telecommunications industry', IEEE Transactions on Engineering Management, Vol. 57, No. 1, pp.144-156.

Rhodes, R.W. (1997) Understanding Governance. Policy Networks, Reflexivity and Accountability, Open University Press, Buckingham.

Ronis, S.R. (2007) Timelines into the Future: Strategic Visioning Methods for Government, Business, and other Organisations, Hamilton Books, Lanham, MD.

Rothwell, R. (1992) 'Successful industrial innovation: critical success factors for the 1990's', $R \& D$ Management, Vol. 22, No. 3, pp.221-239.

Schirrmeister, E. and Warnke, P. (2013) 'Envisioning structural transformation - lessons from a foresight project on the future of innovation', Technological Forecasting \& Social Change, Vol. 80, No. 3, pp.453-466.

Schot, J. (2001) 'Towards new forms of participatory technology development', Technological Analysis \& Strategic Management, Vol. 13, No. 1, pp.39-52.

Schumpeter, A. (1911) Theorie der wirtschaftlichen Entwicklung, Duncker \& Humblot, Berlin.

Steward, F. (2008) Breaking the Boundaries, Transformative Innovation for the Global Good, NESTA, London.

Stirling, A. (2005) 'Opening up or closing down: analysis, participation and power in the social appraisal of technology', in Leach, M., Scoones, I. and Wynne, B. (Eds.): Science and Citizens: Globalization and the Challenge of Engagement, pp.218-231, Zed, London.

Stoneman, P. (2009) Soft Innovation - Towards a More Complete Picture of Innovative Change, NESTA, London.

Sveiby, K-E., Gripenberg, P. and Segercrantz, B. (Eds.) (2012) Challenging the Innovation Paradigm, Routledge Studies in Technology, Work and Organisations, Routledge, New York.

Tuomi, I. (2002) Networks of Innovation: Change And Meaning in the Age of the Internet, Oxford University Press, Oxford.

Van der Meer, H. (2007) 'Open innovation - the Dutch treat: challenges in thinking in business models', Creativity and Innovation Management, Vol. 16, No. 2, pp.192-202.

von Hippel, E. (2005) Democratizing Innovation, The MIT Press, Cambridge, Massachusetts.

Warnke, P. (2011) 'Implementing transformative innovation policy priorities', in JRC-IPTS (Ed.): The 4th International Seville Conference on Future-Oriented Technology Analysis (FTA), Book of Abstracts, Seville.

Weber, K.M. (2005) 'What role for politics in the governance of complex innovation systems? New concepts, requirements and processes of an interactive technology policy for sustainability', in Rosenau, J.N., von Weizsäcker, E.U. and Petschow, U. (Eds.): Governance and Sustainability. Exploring the Roadmap to Sustainability after Johannesburg, Greenleaf, Sheffield.

\section{Notes}

1 For more information see also the webpage: http://www.innovation-futures.org (accessed 15 September 2013). 